\title{
HUMAN AND ORGANIZATIONAL KNOWLEDGE IN A PROJECT MANAGEMENT CONTEXT
}

\begin{abstract}
Purpose - This paper aims to study the improvement of project success in organizations by integrating knowledge management strategies with project management practices in a typical project lifecycle, assuming that the projects are the tools by which organizations achieve the strategic objectives.

All projects are considered successful if they are delivered on time, within budget, with the required features and functions. This could be an indication that project management practitioners have not fully acquired and transferred knowledge learned from past projects to ensure a higher success rate for current and future projects.

The knowledge created in the projects environment in almost any case is lost due to inefficiency of the processes of the enterprise organization. This leads to inefficiency in developing processes and activity already done by the projects organization in previous projects.

The proposal highlights the importance of an intelligent approach to knowledge sharing demonstrated on a practically approved procedure of knowledge sharing on a project management level. Furthermore the concept and process for a successful institutionalisation of Knowledge Management to foster communication and sharing among people is described by a case based through a procedure of "knowledge management in project environment".

This paper doesn't provide a solution to the enterprise problems, this is not a methodology, but like the ISO standard 21500 on project management and PMBOK (Project Management Body Of Knowledge) by the Project Management Institute (PMI) provides the tools by which the organization can manage with effectiveness and efficiency the projects.

Keywords - Project Management, ISO 21500, Continuous improvement, lessons learned, historical information, Knowledge Transfer, Project Lifecycle, Project Success.
\end{abstract}

\section{INTRODUCTION}

The world of project management is an incredible generator of knowledge and before beginning to describe the relationship between project and knowledge, it is possible to describe, shortly, the context of project management.

A project, by the definition of the Project Management Institute (PMI), one of the most important organization in the project management context, is: a temporary endeavor undertaken to create a unique product, service or result a project define a unique deliverable (unique because it is never done by the enterprise organization) developed by a plan, in this way, project for the enterprise organization has a strategic value because it is the tool by which the enterprise organization can achieve its strategic goals. But a project, to achieves its goals, must work with a well defined policies and in a correct cultural context. It is important to define the rules for a correct and efficient Project Management.

\footnotetext{
${ }^{1}$ Antonio Bassi (Eng), Professor of Project Management at SUPSI (The University of Applied Sciences and Arts of Southern Switzerland), Galleria 2, Via Cantonale 2c CH-6928 Manno, mail: antonio.bassi@supsi.ch
} 
What is project management? By the definition of the PMI, it is the application of knowledge, skills, tools and technique to project activities to meet the project requirements. In an enterprise context, the project management defines the strategy to develop the projects and involves the whole organization. In fact, the project management culture involves not only the directions or divisions that develop the project, but all the organization. Project needs the cooperation of all the directions or divisions in the organization (marketing, purchaising, selling, operation ...).

Project, during its lifecycle, produces a lot of documents, like, for example: project documents (plan, strategy, template, ...), meeting minutes, memos, personal and organizational knowledges. All these kinds of knowledge must be managed to improve the knowledge in project management and to enhance the capital assets of the organization to manage, in an effective and efficient way, the project with cost and time reduction, but, unfortunately, in most cases, this knowledge doesn't increase the value of the organization. The cost and time reduction is possibile only through a correct recording of all the knowledge.

But what is the state of the art? The management, due to lack in organizational management, thinks that the recording activities are only loss of time and an inacceptable project cost, and, for their blindness doesn't see the advantages in the next projects by the time and cost point of view.

\subsection{The state of the art}

The Standish Group analyzes, every two years, in its CHAOS report, the performance of projects in various market sectors and in different cultural contexts. This report analyzed more than one hundred thousand projects managed all over the world in every cultural, industry and country context. The picture is quite critical in the regard of the implementation of projects which fail to meet the objectives for whom they were initiated. The last value obtained from this analysis will return a value of about $37 \%$ of projects that have met the customer aspectattive and only one project up to three finished achieving its goals. It is possibile to see a little increment in 18 years.

There is other significant information related to the 'project with problem': if the project doesn't achieves the time goal, the increment in time is nearly the $222 \%$ and for the cost is $186 \%$. In this context the most important thing is to define the causes of these problems. 


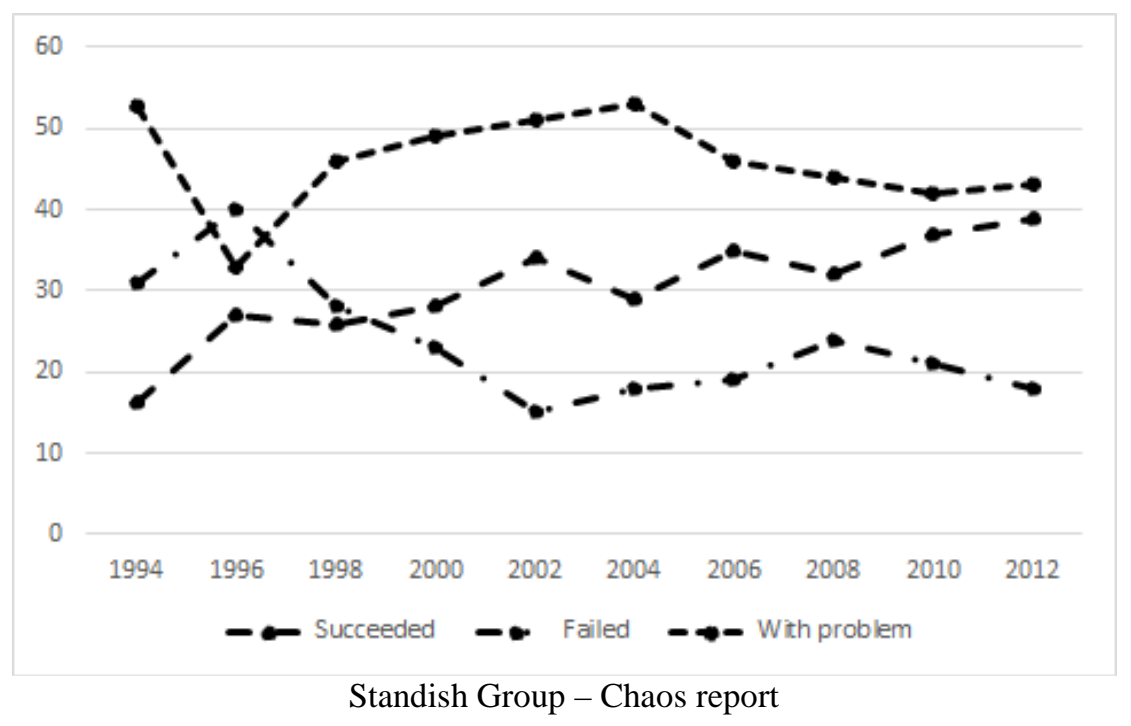

\section{THE CAUSES}

To define the main causes of these problems it is possible to outline three different areas:

- Introduction of an organizational project management culture oriented, which is directly made by the top management of the organization. One of the most important element is the improper closure of a project to collect, catalog and archive the documents / information;

- Improvement of professional skills of project managers so that their behavior can always be directed to the ethics of the profession by allowing a proper and transparent communication within the organization;

Definition of a Knowledge Management system that can handle all the knowledge generated by projects that allow you to store the information and at the same time to deploy it.

The first two areas are analyzed shortly, in the next paragraphs, and more time is dedicated to the definition of a Knowledge Management System.

\subsection{Culture of Project Management}

Recover a famous phrase of Napoleon "There are no bad regiments, only incapable colonels" that is perfectly suited to the organizational context, it is possible to say that it is the management the major source of problems of the organization. If proper guidelines are not distributed and will not supervise that these are properly executed, it cannot be expected that the results will meet expectations. In this context, one of the toughest tasks for which you will have to occupy management is the definition of a strong culture of project management, which, differs from other cultural contexts of the organization (e.g. sales, marketing, ...), are characterized by a vertical development within the 
directions/departments, spread horizontally, because it embraces the whole organizational structure.

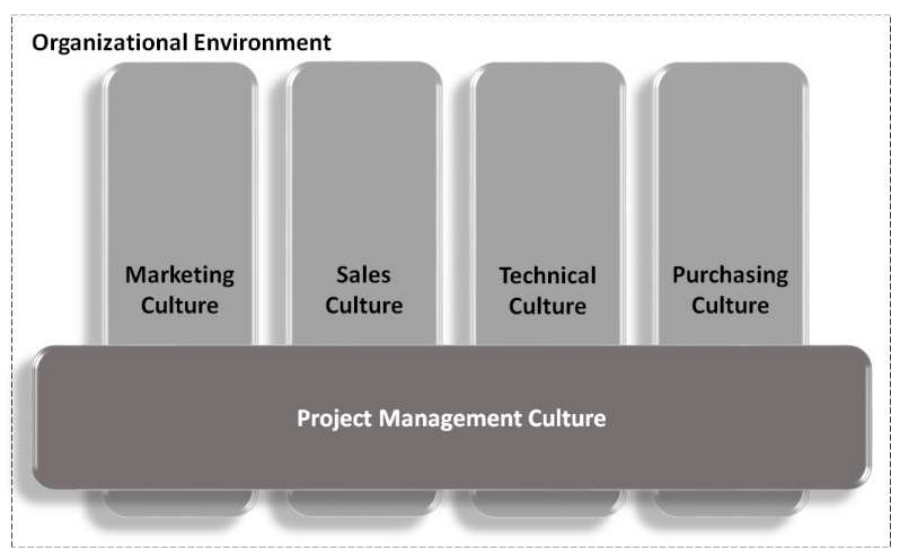

Development of a culture of project management (own source)

But, in many organizations it is possible to observe a drammatical absence of maturity in project management. This is due to a different perception, by the management, in the maturity of their organization because many managers consider the number of projects managed the index of their maturity.

The maturity in project management is made by the definition of strategy, tools, rules and processes to manage projects and in this context it is necessary to define the strategic approach to manage the knowledge made by past projects. In this way the projects can improve the accurancy of the project information to reduce the cost, duration and risk and the uncertainty of the results.

In order to improve the maturity and the project performance, the best approach and the only strategy is the definition of tools and procedures to capture and record all the project information and all the personal and enterprise experience gained during the execution of the lifecycles of the projects.

It is impossibile to stop our activity to manage the information at the end of the project because the strategic value of this information is related to the start phase of the project because this historical information is an important input of the planning phase of the projects. In fact this information is used to better define our plan and to use, for similar projects, parts of past plans, to have a cost, time and risk reduction for the current project.

\subsubsection{Project closure}

The lack of a phase to collect, catalog and archive the documentations, generated during the execution of the project, is the first cause of the failure in the contest of project and knowledge management. The reasons, which at first sight might seem the most plausible, are the lack of resources, time and budget. Often people, due to the pressure of work, are assigned to other projects as soon as the previous project go into the closing phase. But, perhaps, the most plausible explanation is that generally the senior management considers the cost of the closure of the project as an unnecessary cost. 
Another motivation on the human nature that avoids liability due to a job, is not done properly, leads team members and in particular the project manager who has managerial responsibilities to not perform this step, avoiding, in this way, the criticism of the work.

Kerzner observes that people are more likely to document the successes and are more reluctant to document the failures because their name would be inextricably linked to failures, for fear of retaliation.

Thomset compares projects with the "witch hunt", as one of the most ruthless and cynical organizational practices in which the victims (the project manager and sometimes his entire team) are accused by the top management, in any case, for the poor results. He identifies top management has the primarily responsible for the failure. To further substantiate this statement, it is possibile to say that it is the top management who have to define all the directives for a proper project management. Unfortunately, in the majority of cases, this responsibility is ignored, for a variety of reasons ranging from the lack of a strong culture in project management to a wrong perception of reality in their organization.

Murray, however, advocates for greater professionalism of the project manager and his team inviting him to accept the responsibilities independently of the involved factors.

However, in these cases, he sight lose of the real goal that must be pursued. The real goal of the closed phase of a project is the collection and documentation of everything that happened during the execution of the project in order to obtain extremely beneficial in terms of saving and experience, in new projects that will be managed by the same organization.

It's true what Kerzner said, " the only real failures are those in which we learn nothing."

\subsection{Professional skills in Project Management}

The project manager is a professional, and as such he should be formed. Unfortunately, in many companies the growth of this professional is made not through an educational process that should begin with a careful analysis of the candidate's ability but through a mechanism of promotion that elevates the person who stood out for the undisputed technical skills. In this context, it is possible to lose sight of one of the most basic concepts of work and the allocation of responsibilities, which answers the following question: Is the person able to perform the task that is required? Since the role of the project manager is typically aimed at the managerial and not to the technical context, this persons do not always meet expectations because the tasks that will have to play are too far away from what is its working reality.

The main characteristics of a project manager, to manage in a correct way the project, are related to (the first three):

$$
\begin{array}{ll}
\text { - } & \text { Leadership; } \\
\text { - } & \text { Communication; } \\
\text { - } & \text { Problem Solving. }
\end{array}
$$

And now the question: how many project managers, that you know, have these kind of characteristics? In most case the answer could be: very few or nothing. This kind of profession need a very strong characteristics, and this is the answer because not all the persons could be able to manage a project. 
If you need to define the role of a project manager you could define as a: manager. You can notice that the three characteristics listed before are related to managerial skills, and if a project manager needs to manage a great project with one or two hundreds persons and with a budget of 10 millions euros, this project could be quite similar to a little or medium enterprise.

\subsection{Knowledge Management}

In order to make effective and efficient structure for managing projects within an organization is required to have a knowledge management system that archives and, at the same time, make accessible all the information. The information generated by the organization are the lifeblood of all projects. Without them, the project will have:

- Difficulties in planning. Each project within the organization will be managed as «first project»;

- Difficulties in achieving the objectives. The project won't be able to use the historical information to better plan and manage project risks;

- Lack of management. The projects and related processes will not improve.

Consequently, the organization may not:

- Improve their level of organizational maturity.

Let's see how a proper organization of information can be beneficial to the organizations. Therefore, it is needed to start with the evaluation of different types of knowledge that are gained from the projects.

\section{THE KNOWLEDGE OF THE ORGANIZATION}

In an organization there are two different levels of knowledge that must be managed, from the historical information and lessons learned point of view:

- individual knowledge. What the people have learned during the execution of the project;

- Organizational knowledge. What the organization has developed and learned from the management of the projects.

\subsection{Individual knowledge}

Taking Ismail, «poor is the collection of information on how people share knowledge and experience», especially in the context of the project.

It is possibile to propose a theoretical framework, represented in the following figure, which shows, by mean of appropriate motivational and removing those that may be of inhibitory factors in the sharing of knowledge and experiences, a more effective and efficient sharing of knowledge / experience that would help to increase the probability of success of a project. 


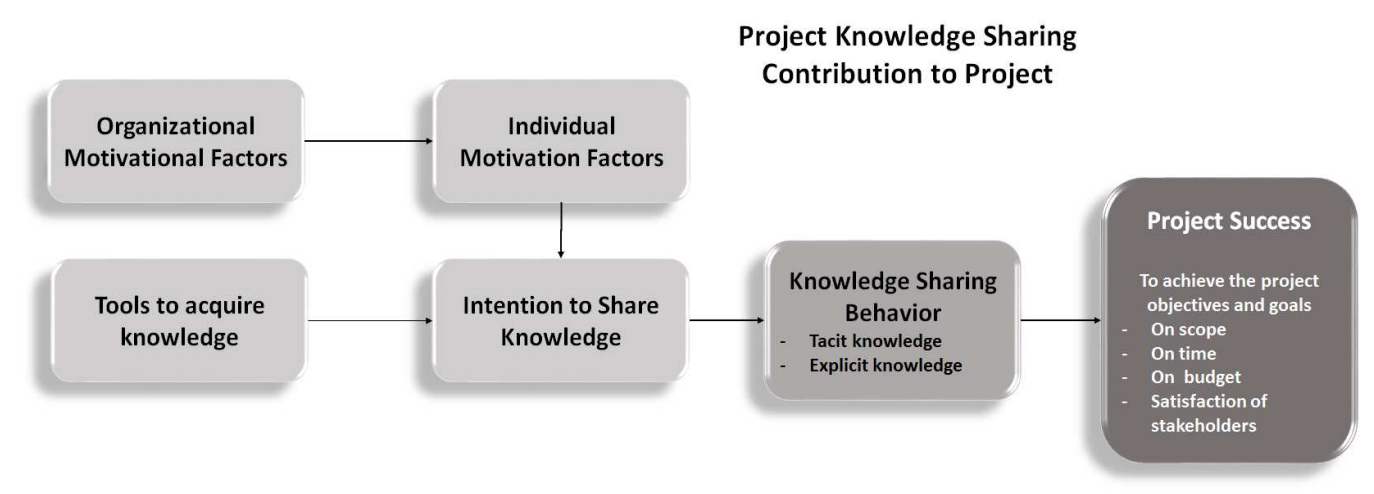

The knowledge of individuals (own source)

This model is based on the " Nonaka 's Knowledge Conversion Model (known as the SECI model)."

It was introduced as one of the most critical elements in the management of knowledge in this context, the management of the tacit knowledge of people. Only through a strong personal motivation, supported by strong motivations from the organization, a person may be willing to share their experience and knowledge. You have to remove the perception of knowledge = power to move towards a model of power = ability to share where people are valued for their ability to share knowledge and experience at all levels of the organization. This involves a radical cultural change in which even the reward systems of people must be rethought. To improve the success of this kind of activity is necessary to have a strong culture in project and knowledge management inside the organization. You need to remember that the main responsibility to define the correct level of organizational culture is for the top management. They are the makers of the success (or insuccess) of the organizational strategy and for the related results.

Referring again to the model proposed by Ismail, it is not entirely correct to say that only through the collection of these knowledge projects can be successful. Success can be achieved through a system of organizational collaboration in which all parties provide their own contribution: Individuals and organization.

To achieve the desired result the organization, as a priority, you must define the strategy by which you can get this information, so you do not only need to motivate people, but to identify the means by which this collection is made possible. The classic tools such as brainstorming, focus groups, and others may no longer be sufficient. It may therefore be necessary to enlist the help of psychologists who help people to give an order to their thoughts and their feelings. It is often just what a person does not have a perfect knowledge but a subtle feeling that might be the key to success in future projects / activities.

\subsection{Organizational knowledge}

The management of projects, through the amount of documentation that is generated, it is an inexhaustible source of knowledge, if properly managed, which can make a significant contribution to the improvement of organizational processes allowing at the 
same time to feed the loop of continuous improvement in order to achieve high maturity models.

In this context the culture of the organization becomes particularly important as it directs all project management organizational behavior and not to the collection, cataloging and information management as well as everything that has been learned in terms of experience (these knowledges are generically classified as Lesson Learned). Skills that are learned from such activities have been planned and executed and those who were their results. By critical analysis of these activities you can get to define what has been done in a correct way and that, therefore, it is fair to replicate in the projects that will be managed as a result but also what has not been done so correctly, but which still brings important elements of knowledge because it forces us to reflect on the causes of failure making us understand mistakes made by drawing at the same time the way so that in the same circumstances, in future projects, you can chose the best strategy. Another strategic element to improve the culture of organizational knowledge is the definition of the correct infrastructure with the related processes. To achieve the success in term of knowledge, the enterprise organization must define the organizational infrastructure to manage all the kind of knowledge. Infrastructure in terms of strategy, tools, procedures, template and resources.

Project Organization Knowledge Sharing

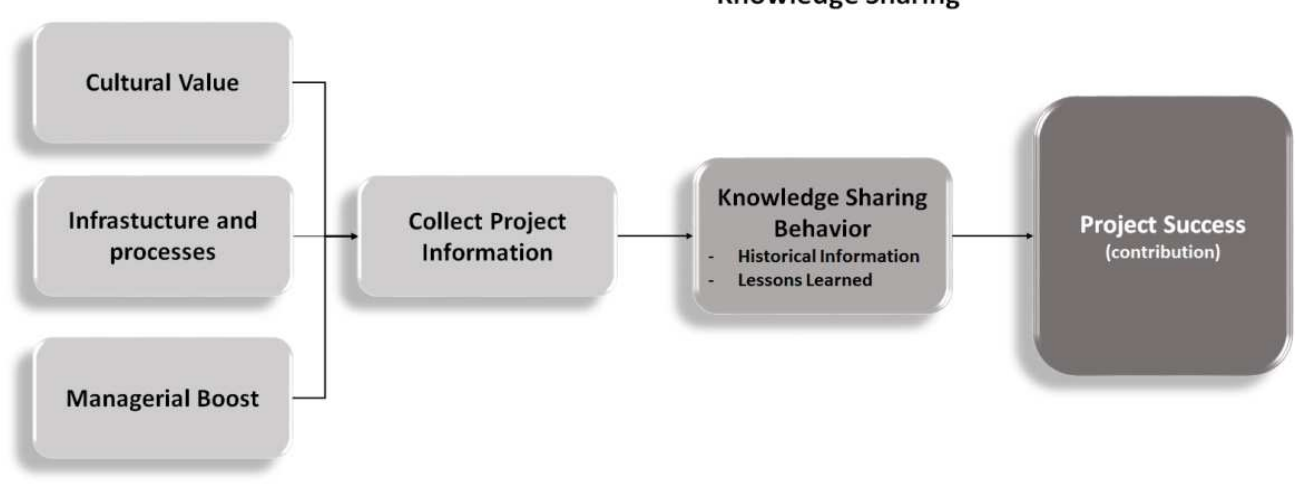

The knowledge of the organizations (own source)

\subsection{The result}

From these two organizational knowledge charts it is possible to outline what could be the framework that organizations can use to manage their knowledge.

Organizational and individual knowledge provided by the organization is the foundation on which the processes of project management can be improved to achieve the results for which the projects have been undertaken. Through this knowledge you have the possibility to identify the weaknesses and strengths of the processes, to improve them and their organizational flow, defining improvement actions that will direct the flow of actions towards the continuous improvement of the organization. 


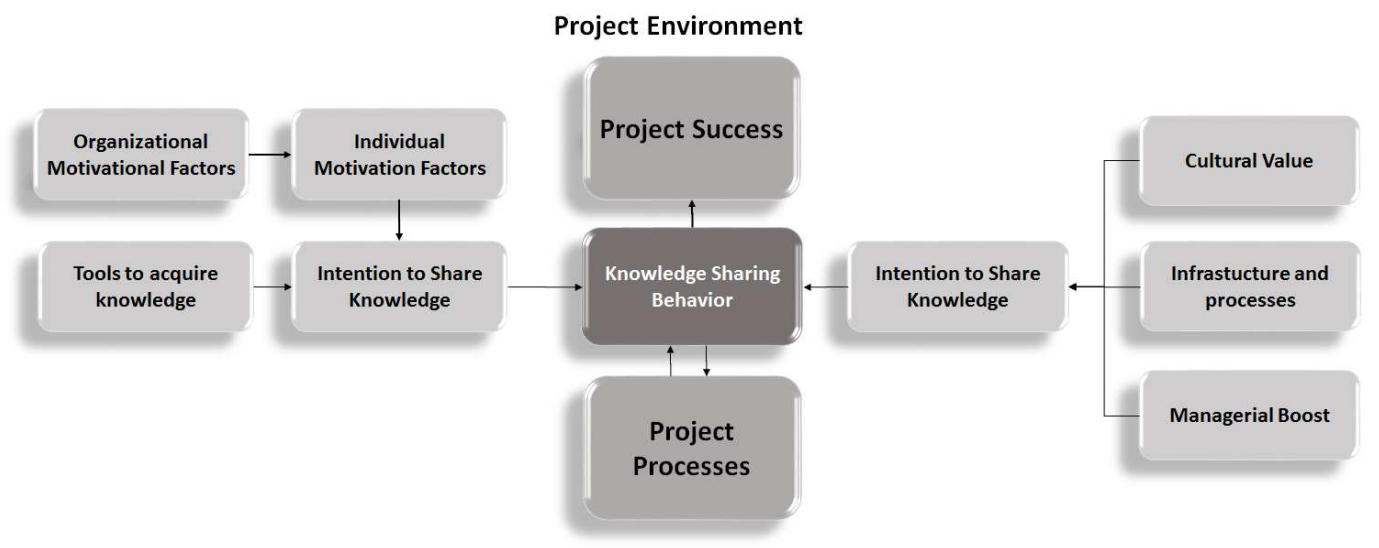

The knowledge in a project context (own source)

Factors of extreme importance are also the tools that technology provides us for the knowledge so that it can be properly managed. There are already technologically advanced tools for knowledge management in the context of a project but you need to have built-in tools that integrate planning tools with these tools of knowledge management.

The characteristics (minimum) of these tools should be:

- Automatic archiving of official documents (design documents, functional specifications, reports, ...);

- $\quad$ Managing the versioning of documents;

- $\quad$ Template management;

- $\quad$ Archiving of documentation for meetings, events and presentations;

- $\quad$ Lessons learned;

- Mail system design with automatic archiving in the database of the project;

\section{WHAT IS THE FUTURE}

After the examination of the current situation with the evidence of the elements that characterized them it is possible to define, to guide our actions, what are the critical success factors of project management in a context of knowledge management:

- $\quad$ Integrated management of knowledge;

- Establishment of a culture of project and knowledge management;

- Continuous improvement of organizational processes.

\subsection{Integrated management of knowledge}

It is necessary, for the project management system, to integrate the management of knowledge in order that the projects can be managed in an effective and efficient way. The processes that govern the management should be defined inn an ideal development project, as defined by the ISO with its standard ISO21500 project management and by the PMI in its PMBOK (Project Management Body Of Knowledge), through the 5 process 
groups: initiation, planning, execution, monitoring, and closure the processes of knowledge management must be insert into the following groups:

- Initiating - projects must benefit from the knowledge of past projects in order to improve the management of the project, through the knowledge and past experience;

- Planning, execution, control - collecting and storing lessons learned gained from the development of the project;

- Closure - recording the lessons learned acquired in this last phase and all the information generated by the project (official and unofficial documents, presentations, memos, reports ...).

In this context, it would be desirable to the 10 knowledge areas (scope, time, cost, risk, ...), that make up the standard ISO21500, to add another one, the management of the knowledge. Only in this case you will have an effective integration between project management and knowledge.

\subsection{Defining a culture of project and knowledge management}

The culture of the project and knowledge management, to succeed, must permeate the entire organization. It must be able to develop horizontally embracing all organizational structures, placing a common factor principles and concepts that are shared by all, taking into account the specificities of each individual feature. A central body must be established which develops, and manages to branch out the principles and guidelines by which the organization can move forward with the knowledge that itself is able to generate.

In this context it is fundamental to have a clear vision not only of the cultural model but even of the strategy to achieve the projects and organizational success. In the following figure it is shown the flow of information and knowledge between the project organization and the organization and in the second part of the figure it is shown the area of interest and influence of organizational structure responsible for managing the knowledge that it is defined as Organizational Knowledge Center (OKC), whose main responsibilities / activities are:

- $\quad$ Definition of means of knowledge management;

- Definition of the development cycle of knowledge in a project structure;

- Definition of the processes of knowledge management in a project context;

- Transformation of knowledge into operational practices (process improvement, defining checklists, troubleshooting);

- Definition of the resources needed to manage and the related costs. 


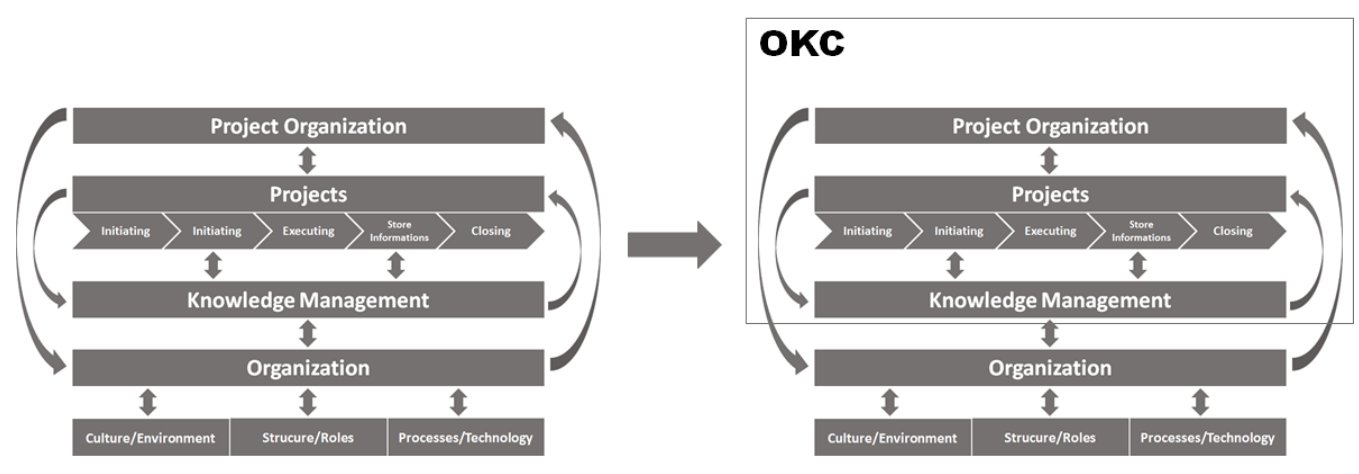

Organizational Knowledge Center (own source)

\subsection{Continuous improvement of organizational processes}

The ultimate goal of an organization is to pursue and achieve the strategic objectives for which the organization was created. In this context, the projects are the tools available for the organization to achieve this. In addition to having to meet the objectives there are the needs to commit itself for the results can be prosecuted effectively and efficiently, this is only possible through the adoption of the Deming cycle (Plan-Do- Check-Act) in the organizational context. By superimposing the cycle to the proposed model (OKC) is obtained by the model described in the image below where:

Plan - during the planning phase of a project the project management plan, and all the information related to the project, will be managed as knowledge (collected, stored and disseminated);

- Do - the context of the project is running the project with the integration of the processes of knowledge management;

- $\quad$ Check - The project collects and analyzes the results;

- Act - the organization and knowledge management component to determine if the actions taken have resulted in benefits for which they were taken, approving those that are valid and rejecting ineffective ones. At the end of this cycle, with these results, you have an improvement of the processes.

The most important thing about this series is the fact that they must be repeated periodically to continuously improve the organizational context / knowledge in which both the company and the people continue to learn and improve. 


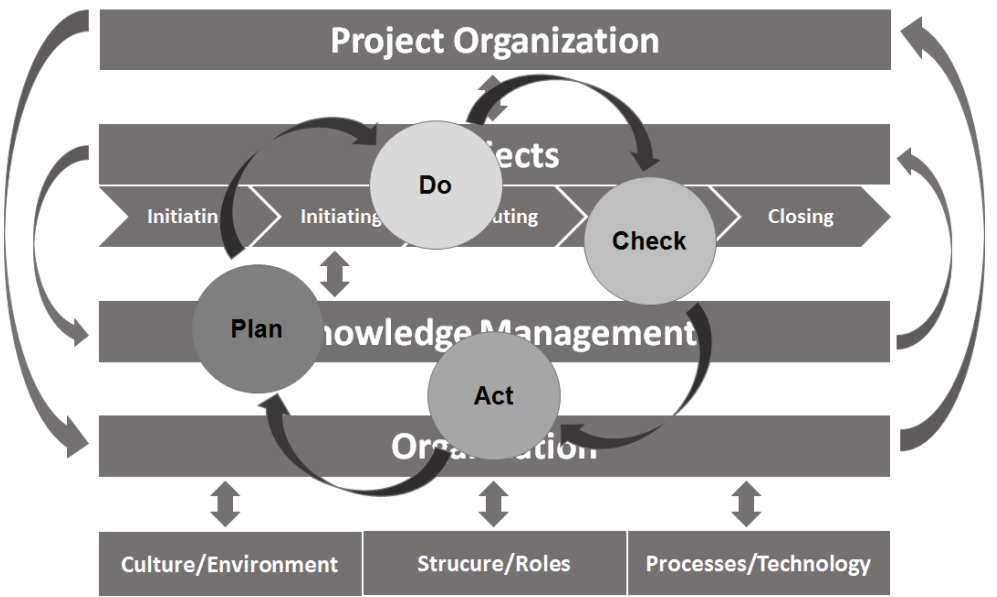

Coninuous improvement of the organization in a project management context (own source)

\subsection{Conclusion}

To take advantage in the knowledge generated within a project in terms of information and experiences you should proceed in these ways:

- $\quad$ Definition of knowledge and project management organizational culture that defines rules and tools to manage the knowledge in relation to the projects management;

Definition of the organizational processes that support the collection of knowledge in an organization.

Only through organizational culture and processes management, the organization will be able to obtain a costs, duration and risk reduction in project management as well as a reduction in the uncertainty of the results. In this way the project will be able to achieve the strategic goals of the organization with effectiveness and efficiency.

\section{REFERENCES}

[1] Bollinger A.S., Smith R.D., Managing organizational knowledge as a strategic asset, ,Journal of Knowledge Management" 2001/5, s. 8-18.

[2] Bower W. D., Development of a Decision Framework for Knowledge Management Projects, Master's Thesis

[3] Air Force Institute of Technology, Wright-Patterson AFB Dayton, OH, 2001.

[4] Cope III R.F., Cope R.F., Hotard D.G., Enhancing project management with knowledge Management principles, Allied Academies International Conference 2006, New Orleans, LA, 2006.

[5] Gudi A., Becerra-Fernandez I., Role of knowledge management in project management of complex systems organizations, NASA Knowledge Management and Successful Mission Operations Conference 2006, Houston, TX, 2006.

[6] Durant-Law G.A., Network Project Management: Visualising Collective Knowledge to Better Understand and Model a Project-Portfolio, CreateSpace Independent Publishing Platform 2012. 
[7] Hanisch B. et al., Knowledge Management in project environments, „Journal of Knowledge Management" 13/4 (2009).

[8] IPMA, IPMA Competence Baseline 3.0, International Project Management Association 2006.

[9] Ismail W.K.W., Nor K.M., Marjani T., The role of knowledge sharing practice in enhancing project success, Institute of Interdisciplinary Business Research 2009/1.

[10] ISO 21500 Guidance on Project Management.

[11] Kaner M., Kami R., Project Knowledge Management with Hierarchical Case Retrieval Networks: Aiding project managers in making complex, Lambert Academic Publishing 2011.

[12] Kerzner H., Project Management - A Systems Approach to Planning, Scheduling, and Controlling, Wiley, New York 2009.

[13] Konda D., Knowledge Management Framework for System Development Projects: Integrated Knowledge Management Framework for Knowledge Enablement of Information Systems Development (ISD) Projects, LAP LAMBERT Academic Publishing 2010.

[14] Krammer C., Knowledge Management in Project Management: Integration of Knowledge Management into a Project Management Process, VDM Verlag Dr. Müller 2010.

[15] Labuschagne P., Knowledge Management - What is Knowledge?, Pieter Labuschagne 2012.

[16] Lim T.T., Organizational Culture and Knowledge Management, DBA thesis, Southern Cross University 2008.

[17] Love P.E.D. et al., Management of Knowledge in Project Environments. Elsevier, Oxford 2005.

[18] Love P.E.D., Sik-wah Fong P., Irani Z., Management of Knowledge in Project Environments, Routledge 2005.

[19] Lundin R.A., Koshkinen K.U., Pihlanto P., Knowledge Management in Project-Based Companies: An Organic Perspective, Palgrave Macmillan 2008.

[20] Milton N., Knowledge Management for Teams and Projects, Chandos Publishing 2012.

[21] Msoroka M., Project Design and Management Knowledge and Project Management Skills, GRIN Verlag 2012.

[22] Nonaka I., The knowledge-creating company, „Harvard Business Review” NovemberDecember 1991.

[23] O'Shea K., Project Managers: what do they really do and need to know? Project Management Knowledge and Application, VDM 2009.

[24] Oluikpe P., Knowledge Management: A Project Management Approach, Authorhouse 2011.

[25] Owes N.R., Modern Project Management: Successfully Integrating Project Management Knowledge Areas and Processes, Amacom 2001.

[26] Owen J., Integrating knowledge management with programme management, In: Current Issues in Knowledge Management, ed. M.E. Jennex, IGI Global, New York 2008.

[27] PMI, PMBOK, Project Management Institute 2012.

[28] Srikantaiah T., Srikantaiah T.K., Koenig M.E.D., Hawamdeh S., Convergence of Project Management and Knowledge Management, Scarecrow Press, Lanham 2010.

[29] Standish Group, CHAOS report, 2012.

[30] Turner J.R., The Handbook of Project-Based Management, Mc-Graw Hill, London 2009.

[31] Yeong A., Lim T.T., Integrating knowledge management with project management for project success, „Program \& Portfolio Management” 1/2 (2010).

[32] Wasielewski E., Project Knowledge Management: Systematic Learning with the Project Comparison Technique, Springer 2012.

\section{WIEDZA ORAZ UMIEJĘTNOŚCI ORGANIZACYJNE W KONTEKŚCIE ZARZĄDZANIA PROJEKTEM}

Artykuł ma na celu ukazanie w jaki sposób projekt może odnieść sukces w przedsiębiorstwie poprzez zintegrowanie strategii zarządzania wiedzą z praktykami 
zarządzania projektem w typowym cyklu jego życia, przy założeniu, że projekt ten jest narzędziem, dzięki któremu organizacje są w stanie osiągnąć cele strategiczne.

Wszystkie projekty są uważane za skuteczne, jeśli są one dostarczane na czas, w ramach budżetu, oraz gdy posiadają wymagane cechy i funkcje. Jest to więc przesłanka, że wiedza wyniesiona z poprzednich projektów nie została przekazana przez praktyków zarządzania projektem w taki sposób, aby zapewnić wyższy wskaźnik sukcesu dla obecnych i przyszłych projektów.

Wiedza stworzona w środowisku projektów w prawie każdym przypadku jest wiedzą utraconą z powodu nieefektywności procesów organizacji przedsiębiorstwa. Prowadzi to do nieefektywności w rozwoju procesów i czynności już wykonanych przez organizację w poprzednich projektach.

W artykule podkreślono znaczenie inteligentnego podejścia do dzielenia się wiedzą na poziomie zarządzania projektem. Koncepcja i sposób dzielenia się wiedzą i przekazywania jej w celu skutecznej komunikacji została opisana w procedurze "zarządzania wiedzą w środowisku projektu". Artykuł nie jest sposobem na rozwiązanie problemów przedsiębiorstwa, nie jest to również metoda, ale zarówno normy ISO 21500 w zakresie zarządzania projektami oraz PMBOK (Project Management Body of Knowledge) i Project Management Institute (PMI) dostarczają otrzebne narzędzia, dzięki którym organizacja może zarządzać projektami skutecznie i efektywnie.

Słowa kluczowe - Zarządzanie projektem, ISO 21500, ciągłe doskonalenie, wnioski, informacje historyczne, transfer wiedzy, cykl życia projektu, sukces projektu

\section{DOI: 10.7862/rz.2014.mmr.29}

Tekst złożono w redakcji: wrzesień 2014

Przyjęto do druku: wrzesień 2014 